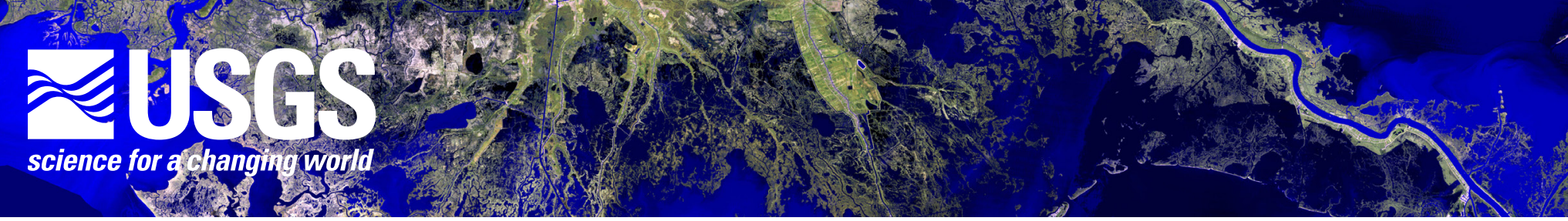

\title{
Trends and Causes of Historical Wetland Loss in Coastal Louisiana
}

\section{Project Summary}

Wetland losses in the northern Gulf Coast region of the United States are so extensive that they represent critical concerns to government environmental agencies and natural resource managers. In Louisiana, almost 3,000 square kilometers $\left(\mathrm{km}^{2}\right)$ of low-lying wetlands converted to open water between 1956 and 2004 (fig. 1), and billions of dollars in State and Federal funding have been allocated for coastal restoration projects intended to compensate for some of those wetland losses. Recent research at the St. Petersburg Coastal and Marine Science Center (SPCMSC) focused on understanding the physical processes and human activities that contributed to historical wetland loss in coastal Louisiana and the spatial and temporal trends of that loss.

The physical processes (land-surface subsidence and sediment erosion) responsible for historical wetland loss were quantified by comparing marsh-surface elevations, water depths, and vertical displacements of stratigraphic contacts at 10 study areas in the Mississippi River delta plain and 6 sites at Sabine National Wildlife Refuge (SNWR) in the western chenier plain (fig. 1). The timing and extent of land loss at the study areas was determined by comparing historical maps, aerial photographs, and satellite imagery; the temporal and spatial trends of those losses were compared with historical subsidence rates and hydrocarbon production trends.

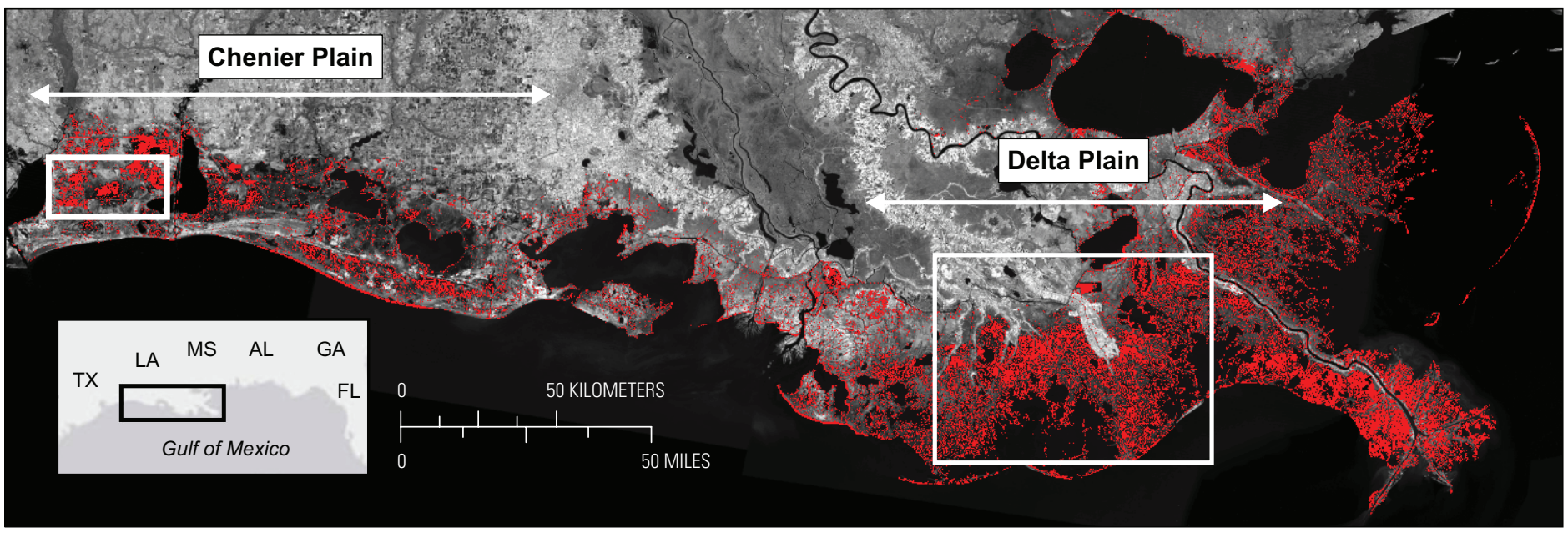

Figure 1. Satellite image of coastal Louisiana showing extent of historical (1956 to 2004) wetland loss (in red). White boxes encompass study-area locations in the western chenier and delta plains. Landsat 5 Thematic Mapper image acquired December 13, 2006.

\section{Geologic Setting}

The Mississippi River delta plain was constructed from fluvial sediments that were deposited in overlapping delta lobes. Thick peat deposits that accumulated in interdistributary areas underlie the modern delta-plain wetlands. In comparison, the chenier plain was constructed by the alongshore progradation of broad mudflats capped by thin peat deposits and wetland vegetation with intervening narrow, sandy beach ridges (cheniers).

The 10 delta-plain study areas encompassed several different physiographic settings, including (1) an upper deltaplain levee flank of the Mississippi River, (2) a preexisting upper delta-plain interior channel, (3) four upper delta-plain interdistributary areas, (4) three lower delta-plain interdistributary areas, and (5) a lower delta-plain beach-ridge margin area. The six western chenier-plain study areas were located in Sabine National Wildlife Refuge (SNWR), which occupies a broad, shore-parallel, low-lying area that formed between the higher elevation beach ridges along the gulf shoreline to the south and upland areas to the north.

\section{Historical Wetland Loss}

In the upper delta plain, extensive areas of formerly emergent marsh converted to open water before 1978, with little significant land-area change since (fig. 2). Analysis of historical aerial photography showed that the most rapid wetland loss at many of these study areas occurred during the late 1960s and 1970s. In comparison, at most of the lower deltaplain study areas, some areas of wetland loss were apparent by the middle to late 1970 s, but the majority of historical land loss occurred between 1978 and 1990. 
At some sites, areas of formerly continuous marsh were alternately emergent or partially submerged on historical aerial photographs acquired prior to 1978, depending on whether the images were acquired under low or high water conditions, respectively. Between 1978 and 1990 , most of these "wet marsh" areas became permanently submerged. In the western chenier plain, most of the historical wetland loss occurred prior to 1978 ; however, some expanses of wet marsh in the western part of SNWR persisted into the 1980s.

\section{Wetland Subsidence and Erosion}

The two primary physical processes responsible for historical wetland loss in coastal Louisiana are land-surface subsidence and erosion. These processes create accommodation space, which is described by the difference between the emergent marsh-surface elevation and the existing water depth at a core site (fig. 3). The predominance of subsidence or erosion at the study areas varied by physiographic and geologic setting. Compared with the upper delta-plain interdistributary study areas, where subsidence greatly exceeded erosion, erosion was about equal to or greater than subsidence at most of the lower delta-plain study areas. At all of the delta-plain study areas, organic-rich marsh deposits (peats) were preserved where formerly emergent wetlands were converted to open water. In contrast, erosion generally exceeded subsidence at the western chenier plain study areas, and the thinner peat deposits were mostly eroded at the open-water sites.

\section{Induced Subsidence Related to Hydrocarbon Production}

Historical delta-plain subsidence rates were assessed by analyzing rates of relative sea-level rise derived from tide-gage records, elevation changes at established benchmarks, and Global Positioning System vertical velocities at Continuously Operating Reference Stations. Integration of these data sources indicated that subsidence rates were slow $(\leq 5$ millimeters per year, $\mathrm{mm} / \mathrm{yr}$ ) from 1947 until the mid-1960s, relatively fast $(\geq 10 \mathrm{~mm} / \mathrm{yr})$ from the mid-1960s until the early 1990s,
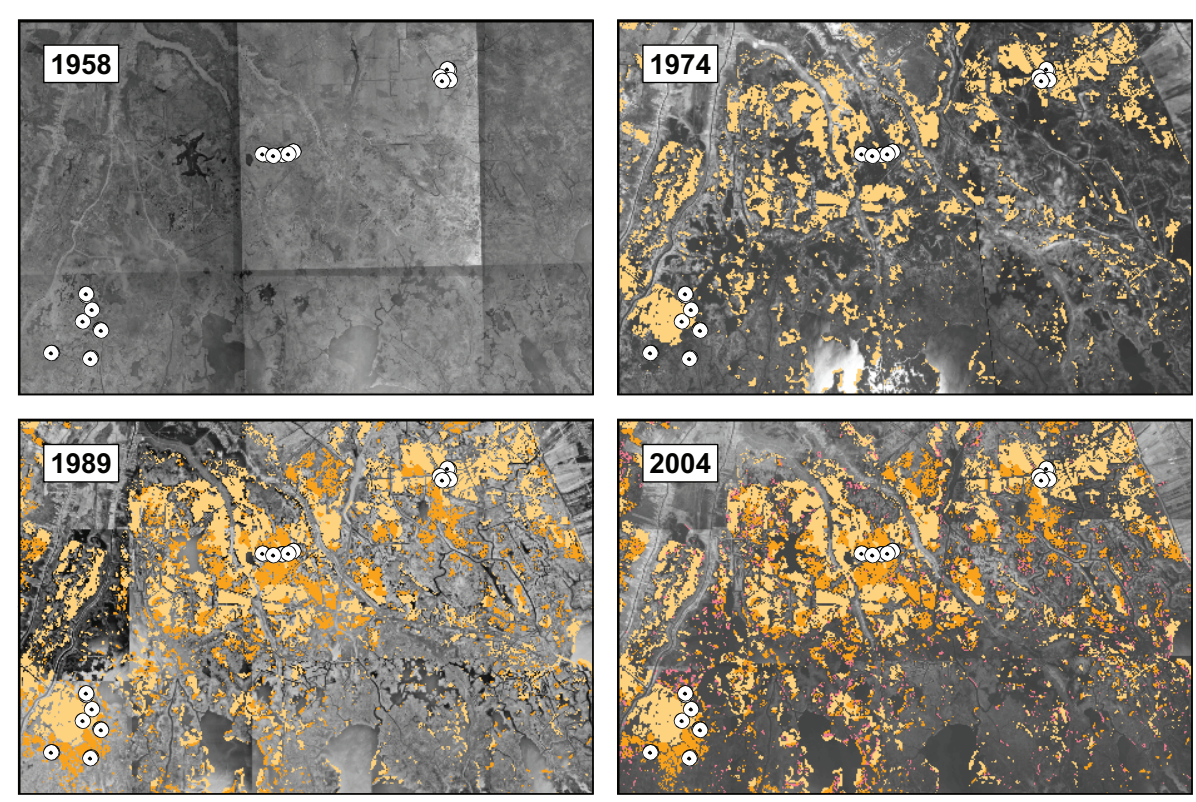

\section{EXPLANATION \\ - Core location \\ 1956 - 1978 land loss \\ 1978 - 1990 land loss \\ 1990 - 2004 land loss}

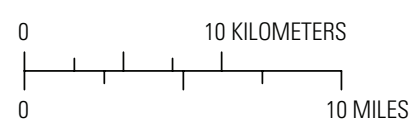

Figure 2. Pre- and post-land-loss aerial photographs overlaid with historical wetland-loss trends at selected upper delta-plain interdistributary study areas. Image sources are: Edgar Tobin Aerial Surveys controlled aerial mosaics (1958), National Aeronautics and Space Administration color-infrared aerial photography (1974), and U.S. Geological Survey Digital Orthophoto Quarter Quadrangles (1989 and 2004). Data sources from which the land-loss trends were derived are: National Wetlands Inventory habitat data (1956 and 1978) and Landsat 5 Thematic Mapper satellite imagery (1990 and 2004).

and then slow since the early 1990s. Subsidence rates for the slow periods were comparable to rates that are attributed to natural processes such as shallow sediment compaction.

Some areas of wetland loss in the Gulf Coast region coincide with some of the Nation's largest oil-and-gas fields. Several lines of evidence support the hypothesis that long-term, large-volume hydrocarbon production resulted in landsurface subsidence and wetland loss in coastal Louisiana. There is close temporal and spatial correlation between rates of historic wetland loss, subsidence, and hydrocarbon production on the Louisiana coastal plain. Peak annual production from onshore Louisiana oil-and-gas fields coincided with the period of greatest wetland loss (fig. 4). In addition, historical subsidence rates measured at benchmarks were generally higher over oil-and-gas fields (fig. 5). Numerical modeling by SPCMSC collaborators at Stanford University confirmed that reservoir depletion and pore-pressure reductions at large oil-and-gas fields in the southern Mississippi River delta plain were capable of inducing land-surface subsid- ence. If accelerated historical subsidence rates and wetland loss were induced by hydrocarbon production, then the recent reductions in subsidence rates likely reflect a balancing of subsurface stresses after production decreased.

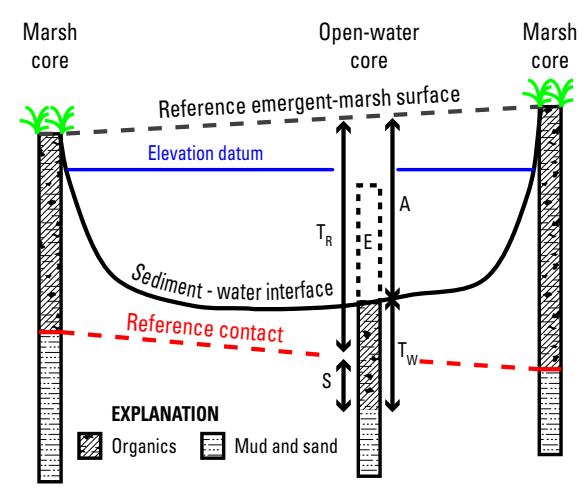

Figure 3. Conceptual diagram showing the stratigraphic relations used to estimate subsidence and erosion at an open-water core site. Abbreviations: $A$, accommodation; $E$, erosion; $S$, subsidence; $T_{R^{\prime}}$ reference stratigraphic thickness; $T_{w^{\prime}}$ stratigraphic thickness in the open-water core. 


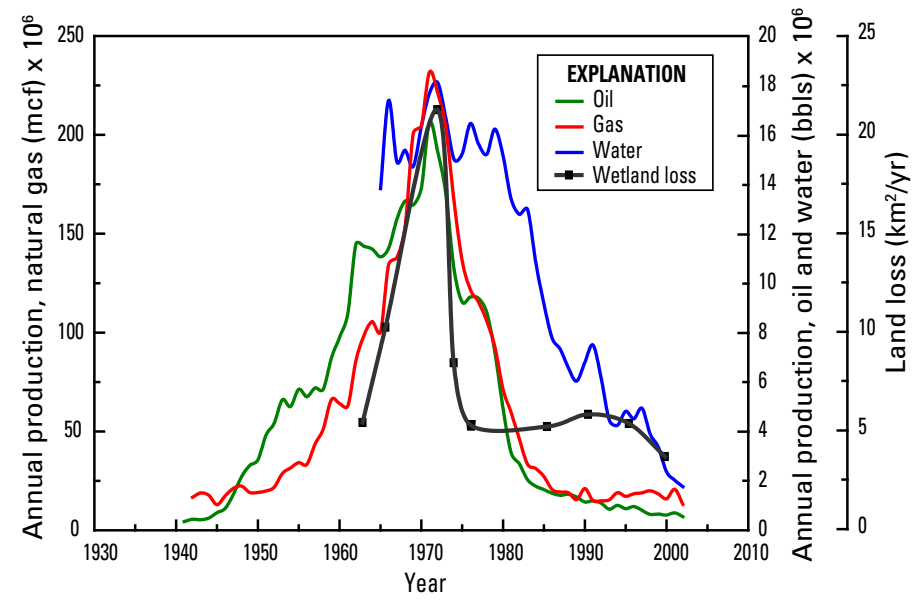

Figure 4. Composite annual fluid production (oil, gas, and formation water) from delta-plain oil-and-gas fields with wetland-loss rates measured at five representative delta-plain wetland-loss hotspots. Abbreviations: mcf, millions of cubic feet; bbls, barrels; $\mathrm{km}^{2} / \mathrm{yr}$, square kilometers per year.

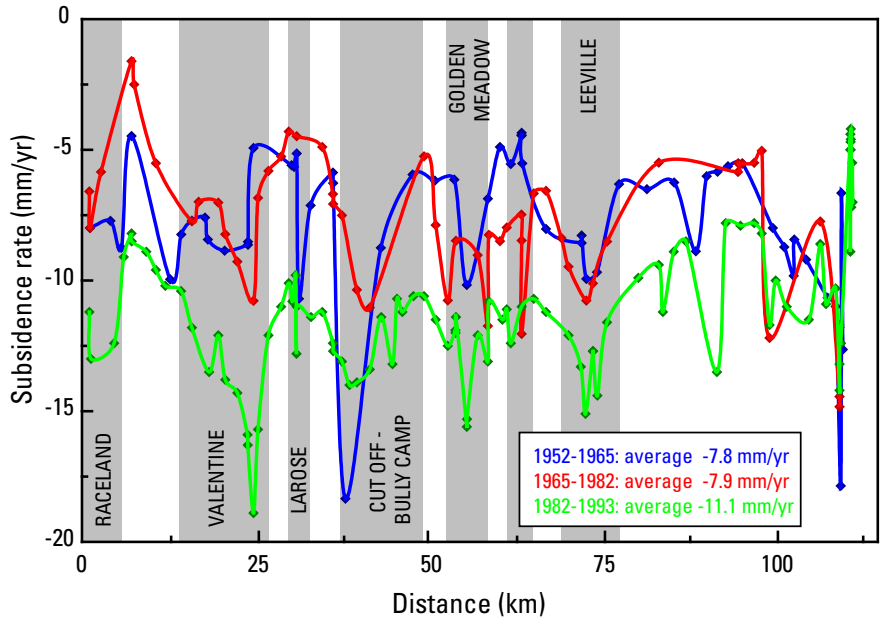

Figure 5. Historical subsidence rates calculated by the National Geodetic Survey from repeat leveling surveys at benchmarks along Bayou Lafource in the delta-plain study area. Shaded areas delineate approximate subsurface extents of nearby oil-and-gas fields. Abbreviations: $\mathrm{mm} / \mathrm{yr}$, millimeters per year; $\mathrm{km}$, kilometers.

\section{Historical}

\section{Accommodation}

\section{Formation}

Accommodation is the space available for sediment accumulation as a result of sea-level rise and (or) land-surface subsidence. Historical conversion of coastalplain wetlands of the northern Gulf of Mexico to open water is an example of accommodation that formed at the decadal scale. Bathymetric data acquired at the study areas (fig. 6) were integrated with the areal extent of historical wetland loss between 1956 and 2004 to estimate the total volume of accommodation space that formed historically on the western chenier and delta plains.

Magnitudes of historical accommodation that formed locally at the western chenier plain study areas (about $20 \times$ $10^{6}$ cubic meters, $\mathrm{m}^{3}$ ) were significantly

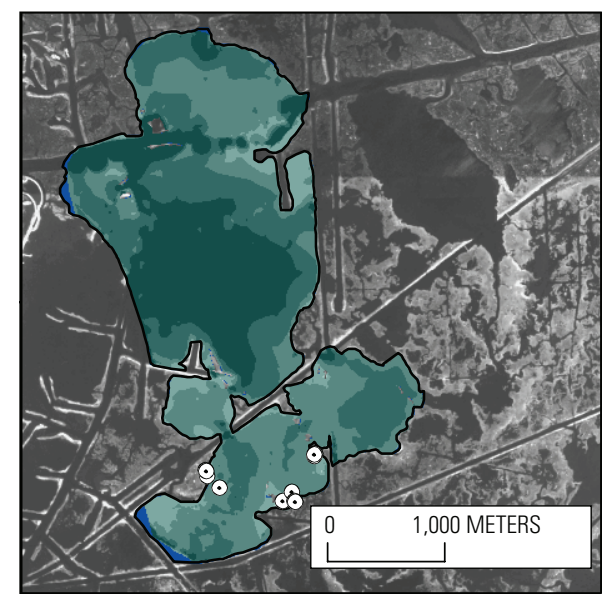

less than formed at the delta plain study areas (about $108 \times 10^{6} \mathrm{~m}^{3}$ ). In part, this reflects the much greater spatial extent of wetland loss and total area in the delta plain (fig. 1); however, normalized magnitudes of accommodation that formed in the western chenier plain are generally less than formed in the delta plain and are significantly less than at some upper delta-plain study areas. These differences are attributed to greater subsidence and, consequently, deeper water bodies and greater accommodation in the delta plain (figs. 6 and 7).

Despite differences in geologic setting, similarities in temporal and spatial trends of wetland loss indicate that historical accommodation formation was likely initiated by similar processes in both the delta and western chenier plains. The importance of land-surface subsidence to initiating delta-plain wetland loss is demonstrated by the fact that erosion was

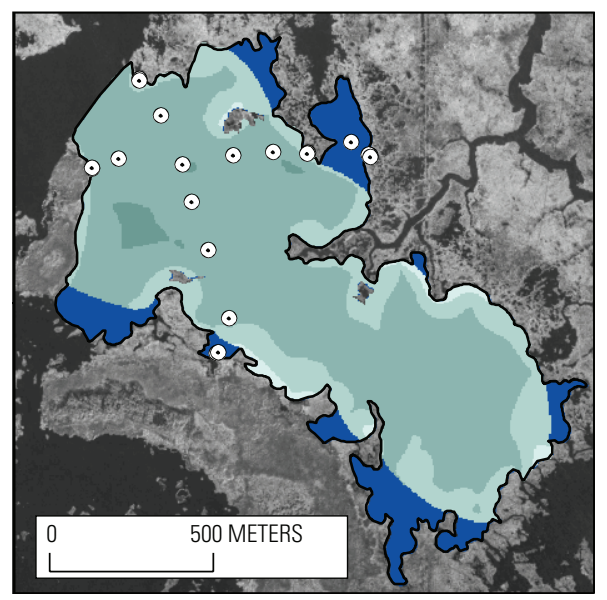

totally contained within the peat section and did not penetrate into the underlying mud and sand, even at sites where erosion exceeded subsidence and extant water depths were greater than the thicknesses of the organic-rich marsh sediments. It is physically impossible to erode to those depths and still preserve some of the marsh deposits. In addition, the expanses of wet marsh that were identified on the historical aerial photography also indicate that subsidence was the process that initiated historical wetland loss. Wet marsh is an intermediate stage in the progression from emergent wetlands to open water and represents nearly uniform drowning of large sections of marsh. In the western chenier and lower delta plains, initial subsidence likely lowered the emergent marshes to a position where they were more susceptible to erosion.

Figure 6. Example bathymetric grids with superimposed core locations from the lower delta plain (left) and western chenier plain (right). Image sources are U.S. Geological Survey Digital Orthophoto Quarter Quadrangles (2004). Abbreviation: cm, centimeters. 


\section{Implications and Future Considerations}

This study provides the first comprehensive analyses of the three-dimensional aspects of historical wetland loss in coastal Louisiana and characterizes the likely causes of those losses. Calculated accommodation volumes provide estimates of the new sediment that would be needed just at the study areas to restore the coastal-plain wetlands to their pre1956 areal extent and elevations. Incorporating these results into project plans may improve wetland restoration strategies. For example, the volume of sediment used to create vegetated earthen terraces around Greens Lake in SNWR (about 0.7 $\left.\times 10^{6} \mathrm{~m}^{3}\right)$ is an order of magnitude less than the total accommodation that formed in the same area between 1956 and 2004. Similarly, at sites where wetland loss was driven primarily by subsidence, structures designed to mitigate shoreline erosion may not be effective.

Considering recent and historical land-loss trends, and given that historical subsidence was not driven entirely by natural processes that would be expected to persist in the future, rates of future accommodation formation in coastal Louisiana will likely be low except for losses associated with episodic storm impacts. For example, about $850 \mathrm{~km}^{2}$ of new water areas formed in coastal Louisiana since 2004 following the passage of Hurricanes Katrina and Rita in 2005 and Hurricane Ike in 2008; however, not enough time has passed to assess which of these changes are transitory and (or) which changes will persist as areas of permanent land loss and new accommodation space.

Increased storm intensities and sealevel rise due to climate change will likely have a significant effect on the resilience of the coastal wetlands along the northern Gulf of Mexico. Understanding the processes driving landscape change, as well as measurements of rates of change, is necessary to characterize the resiliency and fate of these ecosystems and provide scientific support for mitigation and restoration activities. Data from this study characterize historical processes that contributed to wetland change and establish baseline conditions for comparing future change.

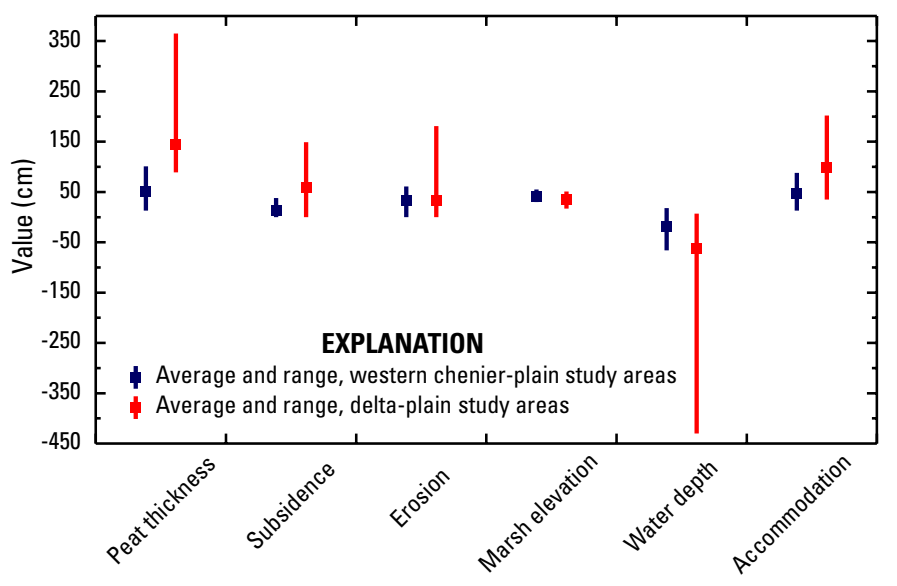

Figure 7. Comparison of one-dimensional (vertical) accommodation parameters and measurements in the western chenier and delta plains. Abbreviation: $\mathrm{cm}$, centimeters.
Both episodic events, such as storms, and gradual sea-level changes leave a signature within the sediment record that can be used to reconstruct environmental conditions through time (fig. 8). Storm deposits and magnitudes of sediment erosion and compaction in near-surface marsh sediments can be measured directly in sediment cores. Temporal elevation measurements can provide rates of change. Together these data provide a comprehensive characterization of the environment over several centuries and can be used to improve predictive capability in modeling future change. In addition, coastal managers are recognizing the need to incorporate subsidence rates into management practices and project designs. These methodologies can be applied to regions across the Gulf of Mexico to develop standardized protocols for monitoring and measurement of coastal and wetland change.
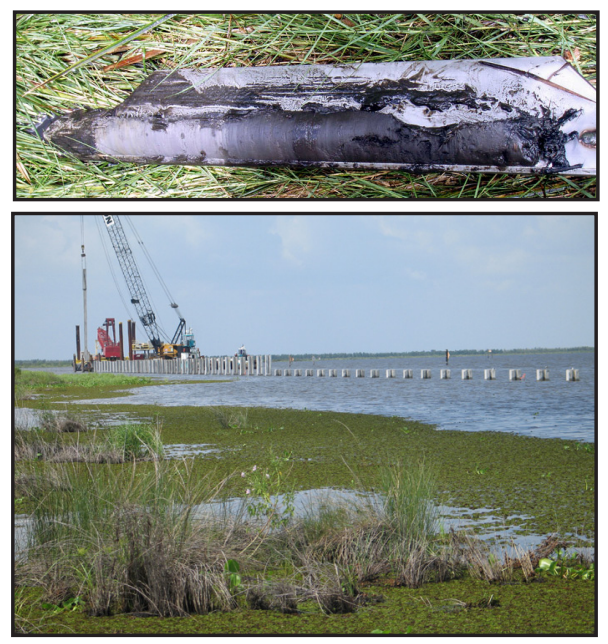

Figure 8. Top: Example of a push core collected at SNWR. Top of the core is to the right. Photograph by Bob Morton (2008). Bottom: Shoreline-protection structure under construction in the upper delta plain. Photograph by Julie Bernier (2007).

\section{Selected References}

- Barras, J.A., Bernier, J.C., and Morton, R.A., 2008, Land area change in coastal Louisiana - A multidecadal perspective (from 1956 to 2006): U.S. Geological Survey Scientific Investigations Map 3019, scale 1:250,000, 14 p. pamphlet.

- Bernier, J.C., Morton, R.A., and Kelso, K.W., 2011, Trends and causes of historical wetland Loss, Sabine National Wildlife Refuge, Southwest Louisiana: U.S. Geological Survey Open-File Report 2011-1169, 36 p., plus app.

- Morton, R.A. and Bernier, J.C., 2010, Recent subsidence-rate reductions in the Mississippi Delta and their geological implications: Journal of Coastal Research, v. 26, no. 3, p. 555-561.

- Morton, R.A., Bernier, J.C., Kelso, K.K., and Barras, J.A., 2010, Quantifying large-scale historical formation of accommodation in the Mississippi Delta: Earth Surface Processes and Landforms, v. 35, no. 14, p. 1625-1641.

- Morton, R.A., Bernier, J.C., and Kelso, K.W., 2009, Recent subsidence and erosion at diverse wetland sites in the southeastern Mississippi delta plain: U.S. Geological Survey Open-File Report 2009-1158, 39 p., plus app. (p. 41-221).

- Morton, R.A., Bernier, J.C., Barras, J.A., and Ferina, N.F., 2005, Rapid subsidence and historical wetland loss in the Mississippi delta plain: Likely causes and future implications: U.S. Geological Survey Open-File Report 2005-1216, 116 p.

\section{Contact Information}

Julie Bernier

U.S. Geological Survey

600 4th Street South

St. Petersburg, FL 33701

jbernier@usgs.gov

http://coastal.er.usgs.gov/gc-subsidence/ 